\title{
Multiple subjectivities: writing Duall's life as social biography
}

\section{Kristyn Harman}

The colonial archive is replete with accounts of the intimacies of life at the frontier in early New South Wales. In reading these records, it is readily apparent that the scribes who mentioned an Indigenous presence had a habit of situating such people at the periphery of colonial society. More often than not, Aboriginal people were cast as supporting actors to the white male leads valorised in accounts of early exploration and settlement. Despite their textual marginalisation, such archival records remain a rich resource for those wanting to appreciate more fully Indigenous contributions to early colonial New South Wales.

Reading archival records against the grain has in recent years been embraced as a practice that holds out the potential to resituate indigenes in more active roles, allowing an increasingly complex and nuanced picture of frontier life to emerge. At the same time, this practice raises a methodological issue as to how such lives might best be reinterpreted and represented for a present-day readership. Before discussing how I have dealt with this conundrum in a recently completed research project, let me set the scene with a brief illustrative example. The three anecdotes that follow are sourced from archival records describing a series of events that unfolded in New South Wales between 1814 and 1819. Their inter-relationship will be made evident shortly.

In 1814 a party of young men returned to an area to the west of Sydney known as the Cowpastures from an overland journey to a tract of country renamed Argyle by the settlers. One of the youthful companions had travelled across this landscape numerous times. Aged about 17, he was a local Dharawal man whose knowledge and relationships to country and people enabled the expeditionary party to traverse the landscape with confidence. One of the men accompanying him was Hamilton Hume. This journey has since been venerated as Hume's first voyage of 'discovery'. ${ }^{1}$ At the time of the expeditionary party's return, the Cowpastures was afflicted by drought. ${ }^{2}$ Rising tensions over competing land use practices were exacerbated by an influx of settlers that saw increasing numbers of Indigenous people displaced from their tracts of country. Other indigenes were seeking to negotiate some kind of accommodation with the newcomers. Conflict between settlers and Indigenous peoples escalated, reaching a crisis point in 1816. A report in the Sydney Gazette identified one of the local Indigenous people as a leader amongst his people, a man who 'excited and encouraged' others in 'committing various atrocious acts of robbery, depredation, 
and barbarity'. ${ }^{3}$ Named on a list of 10 most wanted Aborigines circulated by Governor Macquarie, this leader was arrested by the military during a punitive expedition and sentenced to death. ${ }^{4}$ A reprieve was granted, and he was instead transported to Van Diemen's Land as a convict sentenced to seven years banishment. ${ }^{5}$ Three years later, in 1819, another of the many exploratory expeditions originating from the Cowpastures was co-ordinated by the colonial surgeon and administrator Charles Throsby, a man later celebrated as the first white person to negotiate a direct route from the Cowpastures to Bathurst. Indigenous guides and interpreters accompanied, and indeed led, Throsby just as they had Hume and other celebrated white explorers. ${ }^{6}$ Following the successful completion of the journey, these Indigenous men were awarded brass breastplates and blankets for their services while Throsby and his white retinue received substantial land grants. ${ }^{7}$

These various colonial representations - the figure of the Indigenous guide on Hume's inaugural expedition, the resistance leader banished to Van Diemen's Land, and the recipient of a brass breastplate and blanket - converge in the body of a man known to the Cowpastures settlers as Duall or Dewal. The rapidly changing subject position allocated Duall by colonial scribes reflects the flux associated with life at the frontier as viewed from settlers' standpoints. Ambiguity is also evident in the range of variant spellings used to inscribe him into the colonial records. Ranging from Duall, Dual, and Doual to Dicall (the latter being a transcription error), careful reading of the contextual information within which these proper nouns are embedded is required in order to be sure that they refer to one and the same person. Writing around Duall's life has posed the challenge of identifying a methodology that allowed exploration and explication of some of the complexities and subtleties inherent in the network of colonial relations within which representations of Duall and other Indigenous convicts were embedded. This article elaborates some of the challenges faced in dealing with various diverse colonial representations of Duall as part of a wider project in which I have focused on Indigenous convicts transported from and within New South Wales during the first half of the nineteenth century. ${ }^{8}$

I am intrigued by 'histories from below'. This influenced me at the outset of this research project to imagine a process whereby it might be possible to recover the life stories of Indigenous convicts. It soon became apparent that, at best, one might anticipate catching the occasional glimpse of them as refracted through the lenses of nineteenth century colonial scribes. Duall, like other Indigenous convicts, was captured in the colonial records only at those moments where his life was considered remarkable in the original sense of the word. Remarks about him reflect those instances when his life events attracted colonial attention, whether favourable or unfavourable. Given that I can never know Duall or claim to be able to represent his lived experiences, it begs the question as to why I 
have proceeded with this particular project? The short answer is that while the colonial records reveal more about the people and society that compiled them than they do about Duall himself, the project is nevertheless important as the colonial forces that shaped this archive are the very same forces that impacted on Duall's lived experiences and shaped his destiny. In addition, as Blaze Kwaymullina recently pointed out, colonial policies and practices in the past have had lasting impacts on Aboriginal families who 'are still bearing the scars today'. ${ }^{9}$ Given that 'the reality of the past [is] inescapably entwined in the present', it is necessary to engage with the past on its own terms in order to understand better its emanations in present-day Australia. ${ }^{10}$

The process of researching and writing Duall's life has not been without its temptations. Within the context of early colonial New South Wales the possibility of casting Duall solely in the role of Indigenous resistance fighter or leader holds a certain appeal. Over recent decades a number of other significant Indigenous figures have enjoyed a similar appellation that would not be inconsistent with elements of Duall's colonial career. ${ }^{11}$ Such representations have also been contested. This was particularly evident in the ongoing debate between Keith Windschuttle and Naomi Parry during the 'history wars' over whether the Gai-marigal man Musquito was an 'outlaw ... engaged in a minor crime wave' in 1820s Van Diemen's Land, or was instead a 'prisoner of war' when he was hanged in Hobart Town in 1824 at the onset of the Black War. ${ }^{12}$ In any case, a greater understanding of Duall's importance as an historical actor has emerged through considering the range of subject positions he adopted, or was represented as adopting, at the colonial interface. In aiming to portray something of this complexity, I was inspired by Ian Clark's recent journal article in which he sought to reconcile varying depictions of the well-known Port Phillip personality Derrimut. Taking as his starting point the competing characterisations crafted by Massola, Christie, Christiansen, Griffiths and Barwick, Clark presented what might be termed a 'social biography' of Derrimut in which he highlighted the complex nature of this man's interactions both within colonial society and with Indigenous people. Clark's article is indicative of a shift in the historiography towards more nuanced approaches to the treatment of Indigenous subjects. ${ }^{13}$

When I began researching Duall's life and the lives of other Indigenous convicts I wanted the material uncovered about them to remain central. Rather than dispersing fragments of their recorded lives throughout my writing as pieces of 'evidence', I aimed to adopt a methodology that allowed the men's lives as represented in the archival materials to remain intact. This was intended both as a gesture of respect and to highlight the extent to which such men exercised agency at the colonial interface. The presentation of the research findings therefore became informed by social biography as a methodology, a practice best described as a confluence of biography and social history. In a nutshell, it 
means using biography as a form of historical writing. The principal advantage of social biography in relation to this project is that, as Nick Salvatore has pointed out, it 'treats equally seriously both the subject and the context that shapes that life ... it creates the possibility of a broader understanding of the interplay between an individual and social forces beyond one's ability to control'. ${ }^{14}$ Aiming to achieve that broader understanding has been integral to my research project.

One of the challenges in writing around Duall's life has been an absence of much material relating specifically to him. This issue is common to all the Aboriginal convicts in whom I am interested. This necessitated writing these social biographies as what has been termed 'short lives'. Such biographies achieve what Lytton Strachey described as a 'becoming brevity' but nevertheless serve to illuminate various social and historical processes at work in shaping representations of individual lives. ${ }^{15}$ At times, Duall has received only a passing mention as in the instance of his having been Hume's guide on his inaugural journey of discovery. ${ }^{16}$ On other occasions, events in which he was involved have been elaborated more fully.

Fortunately, the colonial records dealing with the 1816 conflict at the Cowpastures are quite extensive. Investigating this aspect of Duall's life revealed something interesting about the particularities of the relationships in which he was embedded at the Cowpastures frontier. For example, it became evident that while the elite troops from the colonial garrison ordered out by Macquarie were patrolling the district in search of so-called 'hostile natives', some of the settlers at the Cowpastures were willing to risk the hangman's noose by harbouring Indigenous men and their families who were both friends and fugitives. ${ }^{17}$ Throughout this troubled period, Duall was sheltered by John Kennedy, who was none other than an uncle to Hamilton Hume and an explorer in his own right. ${ }^{18}$ Kennedy's willingness to shelter several fugitives, including Duall, demonstrates amongst other things that life at the Cowpastures frontier cohered around a different set of social and economic relationships than those imagined by the colonial administration in Sydney. For example, Kennedy claimed that rather than the murderers that they were characterised as being by the colonial administration, the Aboriginal men he sheltered were 'harmless, innocent men' who protected his farm as well as his neighbour Broughton's property. Were the military to arrest these men, Kennedy claimed, it would result in his having to 'abandon the country'. ${ }^{19}$ Throsby, another Cowpastures resident, was also willing to put himself on the line for local Aboriginal people. His lengthy letters to the Governor to complain about the treatment meted out to indigenes earned Throsby a place on a list of malcontents secretly compiled by Macquarie and sent to England in $1817 .^{20}$ 


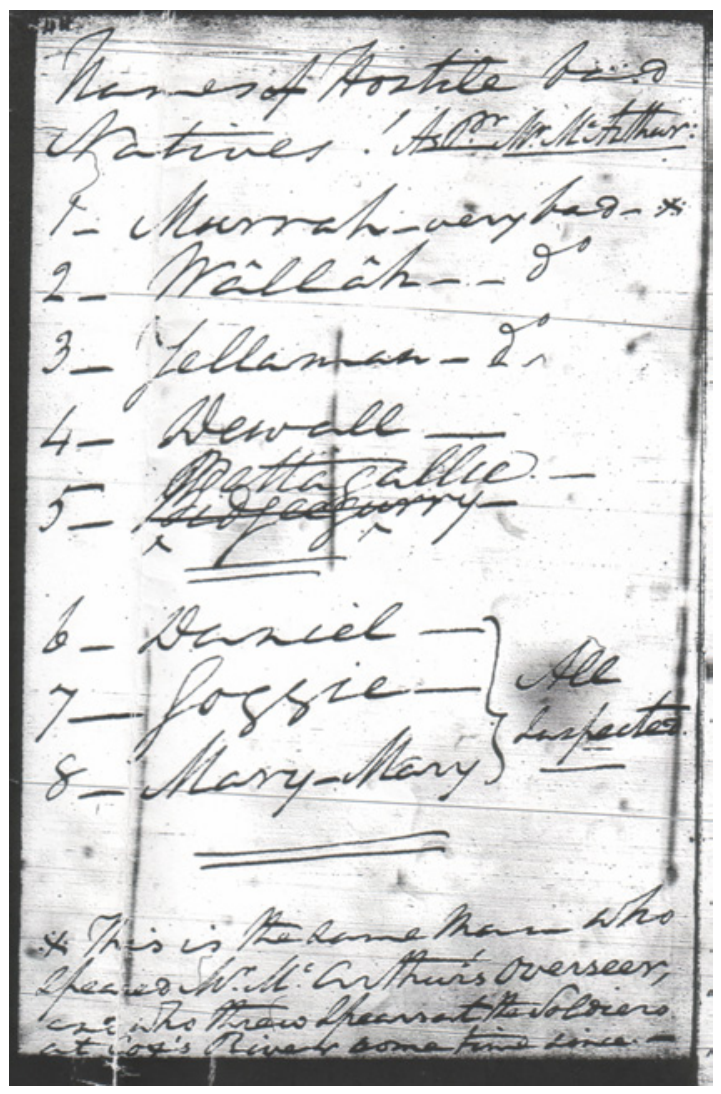

Figure 4.1: Lachlan Macquarie. 'List of hostile natives', New South Wales Colonial Secretary's Office Correspondence, Reel 6005: 44. Reproduced with the kind permission of State Records New South Wales.

Following his capture during the Cowpastures conflict and his subsequent transportation to Van Diemen's Land, Duall simply vanished for a while from the historical record. I know, for example, that his sentence of banishment to Van Diemen's Land was carried out as he is listed as having arrived in the penal colony on the 28 April 1816, on board the Kangaroo. ${ }^{21}$ Unfortunately Duall's convict conduct record for the years he spent in Van Diemen's Land is no longer extant. Contextual material pertaining to this period therefore takes on a heightened significance as it provides a more complete backdrop against which Duall's captivity took place. He was in Van Diemen's Land at a time when local Indigenous peoples still inhabited tracts of their original country and bushrangers were a significant issue to indigenes and the colonial administration alike. ${ }^{22}$ Duall is commonly supposed to have volunteered to work as a blacktracker ${ }^{23}$ alongside Musquito with the 46th regiment to help capture bushrangers during the administration of Lieutenant-Governor William Sorell, although only Musquito is mentioned as a blacktracker in primary sources. ${ }^{24}$ Characterised as 
'bloodhounds', ${ }^{25}$ men such as Duall and Musquito were admired for their tracking skills with the latter being particularly hated by Van Diemen's Land convicts for his involvement in apprehending a number of escapees. ${ }^{26}$

Life in Van Diemen's Land was particularly difficult during the period in which Duall was in exile. Increasing competition over land use led to heightened conflict between Van Diemen's Land settlers and indigenes. At the same time, some of the colonial garrison were openly rebellious and robbed some of the local authorities around Port Dalrymple as well as setting fire to the picket fence surrounding their own accommodation. The administration itself was also fraught by conflict. Convict life during this era was made all the more difficult through a gross shortage of clothing and blankets in conjunction with inclement weather. ${ }^{27}$

While I concur with Salvatore that '[i]t is not enough ... to hang the burden of a traditional social or institutional history upon the inert form of the chosen one, occasionally evoking that body to highlight an interpretative point', it has not proved possible to follow this maxim to the letter. Rather, I have aimed to 'grant the individual his particularity in all its dimensions ... and ... explore these byways wherever they may lead'. ${ }^{28}$ One significant byway involved Charles Throsby's 1819 expedition from the Cowpastures to Bathurst. When a letter arrived in Van Diemen's Land in 1819 from the Colonial Secretary's Office requesting Duall's early return to Sydney, his repatriation was probably sought so that Duall could accompany Throsby as an interpreter. ${ }^{29}$ While researching this expedition might seem tangential, doing so was significant for several reasons not the least of which being, as Terry Goldie so succinctly put it, that 'the role of the white "discoverer" has become a vexing problem for historians in recent years in deciding how a land with an existing population can be discovered'. ${ }^{30}$ I am also interested in working towards redressing one of the silences Henry Reynolds identified in the historiography. While Aboriginal advisers played a crucial role in the white exploration and settlement of Australia 'their role has rarely been fully appreciated in the innumerable historical works which have celebrated the achievements of the explorers who "discovered" inland Australia'. ${ }^{31}$

Considering the journey between the Cowpastures and Bathurst shed light upon some of the broader concerns informing the exile of key Indigenous men. The most obvious of these was competition over land use. From reading records relating to Macquarie's instructions to explorers like Throsby, it became clear that the Governor was single-minded about ascertaining the suitability or otherwise of the country being explored for pastoral and agricultural expansion. This was inextricably linked to a desire to assess the extent to which local Indigenous inhabitants might hamper expansion into such terrain. ${ }^{32}$ With such concerns foremost in their minds, men like Throsby traversed landscape virgin 
to white explorers but well known to their Indigenous guides and interpreters. While doing so, they kept journals detailing their new discoveries. Throsby also wrote letters to the Governor, describing aspects of the journey and recommending rewards for his Indigenous guides and interpreters. ${ }^{33}$ It remains possible to catch glimpses of Duall framed within these pages, although his response to receiving a breastplate and blanket as his reward for participating in the expedition is not recorded. One is left to wonder whether and to what extent he drew a correlation between the bestowal of these items upon his person and the subsequent seizure of further Indigenous lands.

Regardless of how Duall might have viewed the process, transporting Indigenous men from New South Wales to Van Diemen's Land and elsewhere followed a particular pattern in that their exile into captivity followed closely the expropriation of their lands. This was predicated on the notion that such men were British subjects and therefore under the protection of, as well as subject to, colonial law. In the absence of any formal declaration of war or recognition of Aboriginal sovereignty, their acts of political resistance were transmuted into criminal activity. As well as banishment into exile at the behest of earlier colonial governors, from the 1824 inception of the Supreme Court of New South Wales this resulted in sentences of death, imprisonment, or transportation for those who appeared before the colonial judges. Others of course were dealt with summarily under the euphemistically termed method of 'frontier justice'. ${ }^{34}$

To conclude, following as much as can be elucidated about Duall's life-course from the colonial records and contextualising this through utilising social biography as a methodology provided a useful approach. Engaging with some of the by-ways in the records about Duall's life elucidated not only aspects of his individual experiences but also revealed some interesting dynamics driving broader colonial society. That has been one of the key benefits in utilising social biography to inform my methodology in writing around Duall's life. Obviously this exploration has been hampered by considerable constraints, not the least of which being the sparse records relating to Duall that are extant. The most conspicuous absence, though, is any material relating to Duall's life beyond the colonial interface. His Indigenous life beyond the parameters of the frontier remains as inaccessible as his interiority. Captured by the colonial garrison with traces remaining in colonial newspapers, journals, official correspondence, and convict records, Duall as an historical actor remained elusive. He stayed an ephemeral figure who managed to escape detailed scrutiny.

As closing vignettes, I would like to linger for a moment over several images of an older Duall, restored to his people and place. In 1826, Duall was recorded as being one of the 'chiefs' who enjoyed 'roast and boiled beef, soup, plum pudding, and grog' at the annual gathering hosted by the Governor at Parramatta. ${ }^{35}$ The following decade, in 1833 and aged around 40, Duall was living at the 
Cowpastures with his wife and their child. When the distribution of blankets took place that year, he was provided for as he had been a so-called 'good native' throughout the proceeding year. Duall was thus reinscribed in the subject position 'friendly native' that characterised his first recorded interactions with some of the colonists as a young expeditionary guide to Hamilton Hume, and to which he was restored when working as a translator in New South Wales following his early recall from exile. ${ }^{36}$

\section{References}

\section{Primary Sources}

\section{Archival files, Archives Office of Tasmania:}

Assignment Lists and Associated Papers, CON13/1: 65.

New South Wales Colonial Secretary's Correspondence, 1788-1825, Reel 6006: 188; Reel 6020: 238, 248; Reel 6034: 77-89; Reel 6038: 47-50; Reel 6045: 50-62; Reel 6065: 44.

Historical Records of Australia, Series I, Volume IX, Library Committee of the Commonwealth Parliament, Canberra.

_ Series III, Volume II, Library Committee of the Commonwealth Parliament, Canberra.

\section{Newspapers}

Sydney Gazette

Sydney Morning Herald

The Australian

\section{Secondary Sources}

Bethall, Llewelyn 1957, The story of Port Dalrymple: Life and work in northern Tasmania, Government Printer, Hobart.

Bonwick, James 1969 [1870], The last of the Tasmanians; or, the Black War of Van Diemen's Land, Libraries Board of South Australia, Adelaide.

Branagan, Jack 1994, The historic Tamar Valley: Its people, places and shipping, 1798-1990, Regal Publications, Launceston.

Clark, Ian 2005, "'You have all this place ... no good have children" Derrimut: traitor, saviour, or a man of his people?', Journal of the Royal Australian Historical Society 91(2): 107-132.

Goldie, Terry 1989, Fear and temptation: The image of the Indigene in Canadian, Australian and New Zealand literatures, McGill-Queen's University Press, Kingston. 
Harman, Kristyn 2008, 'Aboriginal convicts: race, law, and transportation in colonial New South Wales', PhD Thesis, University of Tasmania, Hobart.

Kwaymullina, Blaze 2007, 'Introduction: listening through the heart', in Speaking from the heart: Stories of life, family and country, Sally Morgan, Tjalaminu Mia and Blaze Kwaymullina (eds), Fremantle Arts Centre Press, Fremantle.

Liston, Carol 1988, 'The Dharawal and Gandangara in colonial Campbelltown NSW 1788-1830', Aboriginal History 12(1): 48-62.

Lowe, David 1994, Forgotten rebels: Black Australians who fought back, Permanent Press, Melbourne.

Parry, Naomi 2004a, "'Many deeds of terror": Windschuttle and Musquito', Labour History 85: 207-212.

- 2004b, “Many deeds of error": response to Windschuttle's defence of his view of Musquito', Labour History 87: 236-238.

-2005, 'Musquito c1780-1825', Australian Dictionary of Biography, Supplementary Volume, Melbourne University Press, Melbourne: 299.

_ 2007, "Hanging no good for Blackfellow": looking into the life of Musquito', Transgressions: critical Australian Indigenous histories, accessed on 9 May 2008, <http://epress.anu.edu.au/aborig_history/ transgressions/html/ch07.html>

Perry, Thomas 1963, Australia's first frontier: The spread of settlement in New South Wales 1788-1829, Melbourne University Press, Kingsgrove.

Reynolds, Henry 1990, With the white people, Penguin, Ringwood.

Salvatore, Nick 2004, 'Biography and social history: an intimate relationship', Labour History 87: 178-192.

Sargent, Clem 1996, The Colonial Garrison 1817-1824, TCS Publications, Canberra.

Walter, James 2006, 'The utility of short lives', Biography 29(2): 329-337.

Windschuttle, Keith 2004, 'Guerrilla warrior and resistance fighter? The career of Musquito', Labour History 87: 221-235.

Wise, Christine 1983, 'Black Rebel Musquito' in Rebels and Radicals, Eric Fry (ed), Allen \& Unwin, Sydney: 1-7.

\section{ENDNOTES}

${ }^{1}$ Liston 1988: 60.

${ }^{2}$ Historical Records of Australia [hereafter HRA], Series I, Volume IX, Macquarie to Bathurst, 18 March 1816: 52-53.

3 Sydney Gazette, 3 August 1816: 1.

4 Macquarie 1816, 'List of Hostile Natives', New South Wales Colonial Secretary's Correspondence, Reel 6065: 44, Archives Office of Tasmania [hereafter AOT]. The other Aboriginal people named on this list were Murrah (who was said to have been 'the same man who speared W. McArthur's overseer, and 
who threw spears at the soldiers at Cox's River some time since'), Wallah (alias Warren), Yellaman, Bettagalie, Daniel, Coggie (Cogie), and Mary-Mary.

5 Sydney Gazette, 3 August 1816: 1.

${ }^{6}$ Charles Throsby 1819, 'Journal of a Tour to Bathurst Through The Cow Pastures Commencing on April 25th 1819', New South Wales Colonial Secretary's Correspondence, Reel 6034: 88-89, AOT [Hereafter Throsby 1819]. Duall was a member of this expeditionary party in the official capacity of interpreter.

${ }^{7}$ Government and General Orders, Civil Department, 31 May 1819, New South Wales Colonial Secretary's Correspondence, Reel 6038: 47-50, AOT.

8 Harman 2008.

9 Kwaymullina 2007: 20.

10 ibid.

11 See, for example, depictions of Windradyne, Musquito, Yagan, Jack Napoleon (Tunnerminnerwait), Dundalli, and Jandamurra in Lowe 1994.

12 See Parry 2004, 2005. See also Windschuttle 2004.

${ }^{13}$ Clark 2005. Such a shift is also indicated by Naomi Parry's recently published nuanced interpretation of Musquito's life. See Parry 2007.

14 Salvatore 2004: 187.

15 Cited in Walter 2006: 330.

16 Liston 1988: 60.

${ }^{17}$ Report of Lt. Parker of the $46^{\text {th }}$ Regiment, concerning his detachment's operations at Appin and Journey to the Five Islands, New South Wales Colonial Secretary's Correspondence, Reel 6045: 60-62, AOT.

18 Death Notice for John Kennedy, Sydney Morning Herald, 3 April 1843: 3.

${ }^{19}$ Report of Captain James Wallis of the $46^{\text {th }}$ Regiment, to Governor Macquarie concerning his operations against the hostile natives in the Airds and Appin Districts, 9 May 1816, New South Wales Colonial Secretary's Correspondence, Reel 6045: 50-59, AOT.

${ }^{20}$ HRA, Series I, Volume IX, Macquarie to Bathurst, 1 December 1817: 500.

21 'Government Public Notice and Order: Civil Department', Sydney Gazette, 3 August 1816: 1; Assignment Lists and Associated Papers, CON13/1: 65, AOT.

22 Sargent 1996: 60. See also Branagan 1994: 3-4; and Bethall 1957: 15.

${ }^{23}$ Wise 1983: 3. Duall working as a blacktracker was mentioned by Christine Wise but was not footnoted. Despite searching all Wise's references as well as undertaking exhaustive archival research, I am yet to find any evidence that supports the assertion that Duall worked as a blacktracker whilst in Van Diemen's Land.

24 For a succinct biography of Musquito, see Parry 2005: 299. See also Parry 2007.

25 Bonwick 1969 [1870]: 93.

${ }^{26} H R A$, Series III, Vol II, Sorell to Macquarie, 13 October 1817: 283-284.

27 HRA, Series III, Vol II, Sorell to Macquarie, 8 December 1817: 289.

28 Salvatore 1987: 190.

29 'Transfer of Dicall (Dual) from Port Dalrymple to Sydney', New South Wales Colonial Secretary's Correspondence, Reel 6006: 188, AOT.

30 Goldie 1989: 42.

31 Reynolds 1990: 5.

32 Macquarie's Memorandum, April 1816, New South Wales Colonial Secretary's Correspondence, Reel 6065, AOT.

33 Throsby 1819.

34 Perry 1963: 99.

35 'The Corroborie at Parramatta', The Australian, 19 January 1826: 3.

36 'Return of the Cowpasture Aborigines for 1833', AONSW 4/6666.3, cited in Liston 1988: 58-59. 